\title{
Effect of Market Culture and Hierarchy Culture on the Implementation of Corporate Strategy in Private Chartered Universities in Kenya
}

\author{
Joyce Wanjiku Nderitu ${ }^{1, ~ *}$, Esther Waiganjo ${ }^{2}$, George Otieno Orwa ${ }^{1}$ \\ ${ }^{1}$ School of Business, Jomo Kenyatta University of Agriculture and Technology, Nairobi, Kenya \\ ${ }^{2}$ School of Mathematics, Jomo Kenyatta University of Agriculture and Technology, Nairobi, Kenya
}

Email address:

kagure1976@yahoo.com (J. W. Nderitu), ewaiganjo@jkuat.ac.ke (E. Waiganjo), gorwa@jkuat.ac.ke (G. O. Orwa)

*Corresponding author

\section{To cite this article:}

Joyce Wanjiku Nderitu, Esther Waiganjo, George Otieno Orwa. Effect of Market Culture and Hierarchy Culture on the Implementation of Corporate Strategy in Private Chartered Universities in Kenya. Journal of Business and Economic Development.

Vol. 6, No. 3, 2021, pp. 133-147. doi: 10.11648/j.jbed.20210603.12

Received: February 19, 2021; Accepted: April 24, 2021; Published: July 8, 2021

\begin{abstract}
Organizational culture and strategy are two important factors that contribute to the growth of an organization and its business continuation; and for this to happen, it is important to consider the organizational culture that helps the process of strategy implementation. Universities need the right kind of organizational culture which is a key element of strategy implementation process. The purpose of this study was to investigate the effect of organizational culture on corporate strategy implementation in Private chartered universities in Kenya. The competing values framework was adopted to identify the organizational culture types that are displayed in Private chartered universities. The study adopted a positivist view as it aimed at testing hypotheses derived from a predetermined conceptual framework. Cross-sectional survey research design was adopted and it used both quantitative and qualitative data as it seeks the effect of organizational culture on the implementation of corporate strategy. The accessible population included Registrars, Deans, Directors, Heads of Departments, academic staff, and students' leaders. This study used both stratified random sampling and the target sample size was 198 employees. A pilot testing of 42 participants of the sample population was conducted to improve on validity and reliability. Data from questionnaires was organized, coded, analyzed and converted into quantitative summary reports for analyses using the statistical package for social sciences (SPSS) version 21 as the tool in order to describe the relationships between dependent and independent variables. The study used correlation and regression techniques as well as the analysis of variance (ANOVA) to test the study hypotheses. Correlation analysis was used to determine the effect of organizational culture and corporate strategy implementation in Private chartered universities in Kenya by computing Pearson product moment correlation. A multiple linear regression model was also used to derive inferential statistical indicators like the correlation, coefficient of determination, F-statistics, t-test statistic and the p-value. In this research content analysis method was used to analyze qualitative data. Pearson's correlation analysis was used to test for the existence of multicollinearity. The key finding based on the tests conducted in the study was that the explanatory variables; Market culture and Hierarchy culture had effect on the response variable (Implementation of corporate strategy in Private chartered universities in Kenya).
\end{abstract}

Keywords: Corporate Strategy, Market Culture, Hierarchy Culture, Private Chartered Universities, Organizational Culture

\section{Introduction}

Private higher education in Kenya can be traced to the colonial period when missionaries established schools and colleges for their converts. The first private universities were the St. Paul's United Theological college and Scott
Theological College [1]. In 1970 the United States International University (USIU) established a campus in Nairobi. Private universities in Kenya fall into three categories: Private chartered universities constituent's colleges and those operating on letters of interim authority [11].

A study on factors affecting choice of growth strategies of 
Private universities in Kenya revealed that on the relationship between organizational culture and company's strategy, majority of the participants believed that organizational culture plays a great role in the formulation and development of growth strategies in Private universities [2]. Further, to effectively implement strategies that enhance organizational performance and market competitiveness, universities rely heavily on human resource through organizational culture and the systems that drive this process [3]. Studies have shown that graduates from private universities cannot express themselves and that there are more graduates than the market requires. However, the system of education in these universities concentrates on imparting theoretical skills at the expense of practical skills which is the key to building a vibrant economy. The situation in Private universities needs to be improved as they seek to balance enrollment with quality of education [4].

The importance of organizational culture and its influence on the development and training of professionals has received considerable attention in several areas of study, specifically corporate and business management and organizational effectiveness. The understanding of organizational culture will help university leaders to manage change more effectively and efficiently. Most studies have observed organization culture as one of the factors affecting implementation of strategies $[5,6]$. These studies found that culture is one of the most important factors of success or failure with the greatest possibility to affect organizational improvement; and organizational culture carries critical forces that need to be considered in strategy implementation.

Organizational culture is an important element of effective management practices in higher education institutions. In the past, researchers have studied on the organizational concept in order to provide managerial that is effective in the universities [7]. The rigorous frameworks of strategy formulation are giving place to flexible and dynamic frameworks of strategy implementation that can take today's organizations to a new ways of thinking and action [7]. On the other hand, success in corporate management of an organization and its efficiency calls for creating and accomplishing the new concepts of corporate strategy which are focused on the processes of corporate strategy and its implementation. This gives the best probabilities for creating corporate and competitive advantage [8]. As a result of this, there has been high demand of new forms of managerial thinking, organizational cultures, global mindsets, considerable strategic and structural flexibility, and innovative methods for implementing strategies in the business frontier are in dire need [9].

The mandate of the Commission for University Education is to ensure the maintenance of standards, quality and relevance in all aspects of university education, training and research. The Commission mainstreams quality assurance practices in university education and encourages continuous improvement in the management of the quality of university education [10]. Universities need the right kind of organizational culture which is a key element of strategy implementation process [12]. Studies have been done on the subject of organizational culture and the influence it has on other organizational variables especially in the 1980s. As a result of these studies, the subject has become popular among the managers who have understood that organizational culture could affect organizations and implementation of their strategies [13]. Organizational culture and strategy are two important factors that contribute to the growth of an organization and the continuation of its business; and for this to take place, it is important to consider the organizational culture that aids the process of strategy implementation [14]. There is a gap between implementation of generic competitive strategies and the organization's culture dimension [15]. Therefore the purpose of this paper was to investigate the effect of organizational culture on corporate strategy implementation in Private chartered universities in Kenya.

In Kenya, studies show that there are challenges of strategy implementation and that institutional culture plays an important role in determining the success of strategic planning and implementation in any organization. The compatibility of the organization's culture to new strategic changes is an important measure in strategy implementation and mitigation of any challenges that may arise during implementation. Lack of synergy between strategy and culture may obstruct the smooth implementation of strategy by creating resistance to change. It is important that the culture of an organization be well-suited with the strategy being implemented because where there is incompatibility between strategy and culture, it can lead to a high organizational resistance to change and lack of motivation, which can frustrate the effort to strategy implementation [15].

One of the most important reasons affecting the implementation of a strategy in a higher education institution is because of the high level of professionalism which dominates the academic task [16]. Professional autonomy is related to the execution of strategic management. A higher education institution is dependent on the attitude of the professionals. These professionals possess the desirable expertise for the development of the strategy and the necessary expertise for the execution of it [16]. Professionals are capable of using this power advantage because they are not a homogeneous group. For example, their wishes and interests can differ with the faculty or department's interests, and it becomes difficult to develop and execute a (educational) corporate strategy that takes into account all these different visions. The passion of the professional is related to his discipline and not to the organization, and the execution of an intended strategy cannot therefore be taken for granted [17].

At its beginning, the strategic plan in post-secondary education was viewed as a tool to articulate institutional mission and vision help prioritize resources, and promote organizational focus. As a result, many of the early strategic planning efforts produced documents that described the institution, but did little to motivate a process. These 'shelf documents' often sowed the seeds of discontent within the institution, since many who participated in the process spent long hours on the plans development and then saw relatively little implementation [18]. Institutions of higher education in 
Kenya have been forced to reexamine their operation and position themselves by matching organizational strengths and resources with changes in the environment, and this will help them to take advantage of opportunities and overcome or circumvent threats. In positioning themselves, these organizations are supposed to make appropriate strategic choices that are consistent both at the corporate and business unit level. That is why in recent times, the operations of universities are guided by strategic plans that furnish strategies to achieve their vision and mission [19].

Effective use of knowledge is becoming the most important factor for creating wealth and improving social welfare and for international competitiveness. Implementing Kenya Vision 2030 will require more knowledge-based skills [21]. The Kenya Vision 2030 is based on the realization that in an increasingly knowledge-based and globalized world, Science, Technology and Innovation (ST\&I) are essential, both for social and economic progress and for global competitiveness of the nation (Ministry of Education, Science and Technology Strategic Plan, 2013-2017). In view of this, there is need to know the relationship between organizational culture on strategy implementation in higher education institutions. The Ministry of Higher Education Science and Technology (MOHEST) formulated its strategic plan to guide and promote integration of ST \& I, Higher and Technical Education that is focused in all sectors of the economy. Specific emphasis is placed on identified National Priority Growth and Social Sectors that have high potential to harness ST\&I, Higher and Technical Education in attaining the targeted $10 \%$ annual economic growth and social development for the Kenyan people. In order to realize the above, the MOHEST commits itself to facilitating the identification, acquisition, transfer, diffusion and application of relevant ST\&I, higher and technical education in earmarked sectors of the economy [22].

Several studies in Kenya have been done on factors and challenges that are encountered on strategy implementation in higher education institutions in Kenya [23, 24]. Despite extensive research on challenges of strategy implementation, research has yet to focus on the effect of organizational culture in Private chartered universities in Kenya. Past studies in institutions of higher learning in American, Australian and Chinese contexts have used CVF framework to measure the university culture values that are consistent in those contexts [25]. Theoretical studies on organizational culture and empirical studies on successful strategy implementation have mostly been carried out in developing world [26]. There is need to study the effect of organizational culture and the implementation of strategies in using CVF framework in the Kenyan context. It is imperative to find out any factors that would hinder the strategy implementation in compliance with Commission for University Education [27]. These cultural factors need to be identified and addressed and hence, the need to study the effect of organizational culture on corporate strategy implementation. This study therefore investigated on the effect of organizational culture on the implementation of corporate strategy in the Private chartered universities in Kenya, and to fill the above mentioned gap. The objectives of this paper are to determine the effect of market culture on the implementation of corporate strategy in Private chartered universities in Kenya. And to ascertain the effect of hierarchy culture on the implementation of corporate strategy in Private chartered universities in Kenya.

\section{Literature Review}

The foundation of systems of theory is that all the components of an organization are interrelated, and that changing one variable might affect many others, or if one subsystem fails, the whole system is put in jeopardy. In this regard, organizations are viewed as open systems, continually interacting with the environment. These parts that share feedback among each other can be looked as consisting of four aspects namely: inputs which comprise resources such as raw materials, money, technology, and people; processes, such as planning, organizing, motivating and controlling; outputs such as products and services and enhanced systems productivity. This implies that when one part of the systems is removed, the nature of the system is changed as well. Systems theory helps managers to look at the organization more broadly and recognize the interrelationships among the various parts of the organization and how they are related to each other [28, 29].

Organizations operate within an environment. This environment influences the organizational culture and strategy implementation efforts of any organization. The open systems theory was developed after World War II in reaction to the earlier theories of organizations such as the human relations perspective of Elton Mayo and the administrative theories of Henri Fayol. Open systems theories come in many forms, for example, institutional theorists observe organizations as a means by which the beliefs and social values are embedded in organizational structure and are also expressed in organizational change. One of the strategic planning techniques that provide a useful framework for analyzing the environmental pressures on a team or an organization is called PESTEL, which stands for political, environmental, social, technological, environmental and legal factors. These factors are crucial in advanced strategic management and every organization needs to be aware of this. But it is good to note that each of these factors vary from organization to organization and from business to business. These factors also help an organization to determine the various types and categories of how factors influence its well-being. PESTEL remains a mandatory analysis technique that is usually a part of the larger and more comprehensive SWOT Analysis [30].

In the PESTEL tool, political factors represent the way and the extent to which a government influences the economy and business and they include labor laws, tax policy, tariffs, trade restrictions, environmental law, among others. Economic factors refer to those areas unique to the economy and directly influenced by the economy such as inflation rate, interest rate, economic growth or exchange rate. Social factors refer to demographic factors that comprise the areas such as 
population growth rate, cultural aspects, age distribution and health consciousness. Technological factors refer to automation, incentives, the rate of technological change and Research and development and they in addition other areas including efficient production level, quality, costs, and outsourcing decisions. Environmental factors refer to all the factors related to and influenced or determined by the surrounding environment. They include weather, climate, geographical position, insurance, and climate change. Finally, legal factors to laws directly connected to a business or company and its area of activity, including consumer law, antitrust law, health and safety law, and the law on discrimination [31].

A business is a man-made system which has dynamic interaction with various elements that include environment, competitors, customers, suppliers, labor organizations, the government and other agencies. It is a system of related parts working in conjunction with each other to be able to accomplish a number of goals for the organization and those of the individual participants [32]. The open systems theory has brought about the way people understand organizations and the demands that are placed on the leadership and management. Private chartered universities operate within an environment and they are not independent of the driving factors behind organizational change. Universities benefit from a strong open system's approach especially in understanding the environmental demands and the resulting adaptation in policy and the implementation of their strategies. The PESTEL tool gives factors that put pressure on the Private universities in Kenya such as the political environment [33].

An open systems model stresses adaptation, flexibility and innovation, and the key priority is to create. The model thrives on adhocracy whereby ad hoc decisions depend on external influences [34]. This model would be fitting for the proposed higher education 'mixed economy' shaped by market demands and a knowledge economy [35, 36, and 37]. This theory is therefore relevant for this study because it is fitting for the organizational culture and implementation of corporate strategies in Private chartered universities.

Human resource development is defined as a process of developing and unleashing human potential expertise through the organization development and personnel training and development so as to improve performance [38]. Training is the process of systematically implementing organizational change in order to get better results whereas performance entails the organization, work process and individual or group levels. The core beliefs of human resource development are three. First, that organizations are human-made entities that rely on human expertise establish and achieve goals. Second, that human expertise is maximized and developed through human resource development and should be done for the mutual short term and long term benefit of both the organization and the individuals involved. Third, that professionals are advocates of individual or group work process and organization integrity [39].

The engagement of the human resource development is anchored in three theories which include: the economic theory which captures the core issues of the efficient and effective utilization of resources to meet productive goals in a competitive environment; the systems theory which looks at the complex and dynamic interactions of the environment, organization, work processing and group or individual operating at any point in time, and the psychological theory which is concerned with developing human resources and the socio-technical interplay between systems and people [40].

The three components human resource development (HRD) theories and their integration are visually portrayed as a three-legged stool. The legs represent the component theories and the stool's platform represents the full integration of the three theories into the unique theory of HRD. While the stool rests firmly on the floor or the host organization which in this case are the Private chartered universities, an ethical rug serves as a filter through which the integrity of both HRD and the host organization can be maintained. Achieving successful strategy implementation in the Private chartered universities means that the university management and the employees must be well trained and take ownership of the strategy to get the desired results of the organization, in terms of goal achievement and profitability, efficiency and effectiveness of their products. The HRD process and components alluded to in this research for the implementation of strategies in Private chartered universities has the potential of harmonizing, supporting and shaping the whole institution [41].

When managers, other organizational employees are involved, combined with other organizational processes in strategy implementation are involved, this can result in a variety of institution outcomes [42, 43]. These are the principles in the platform of the HRD theory. Therefore, universities sharpen the skills, capabilities, competencies, and also develop managers in order to relinquish their expertise and improve their delivery in implementing strategies, hence improve the performance of the organization.

The Competing Values Framework (CVF) is one of the models that have been applied to measure a typology of organizational culture, though it is very complicated. Though there are other typology cultures, the CVF is one of the most comprehensive and extended culture typology, and it has been used in many empirical studies [34, 38, 42, and 44]. The model uses two dimensions to group culture into four types. Few authors have exhibited four different cultural orientations which this study has adopted [45, 46]. A series of studies have built upon that and contributed to the development of a matrix of organizational cultures, that is more detailed and sophisticated, and acknowledged under Competing Values Framework [47]. Each quadrant resulted from crossing the two basic dimensions represents a particular model of organizational culture. Any organization may get accommodated into one of the quadrants, and ultimately related to a certain organizational culture model (See Appendix VIII). The quadrants of the CVF refer to hierarchy, market, clan, and adhocracy cultures, respectively [48].

Market culture is type of culture which stresses on the effectiveness on goal achieving. The market operates 
primarily through monetary exchange, as competitiveness and productivity in these organizations. The organizations are dependent on strong external positioning and control [49]. Planning and goal setting in such organizations result into productivity and efficiency. The market culture in an organization is a result-oriented entity that is concentrated on interaction with the external environment, stability and controllability. In this culture, the organization emphasizes competition both outside and inside. Leaders in this culture are tough and demanding competitors, and success is defined in terms of market winning [50]. This type of culture is important in this study because it stresses effectiveness and goal achieving which support strategy implementation. The market operates primarily through monetary exchange, as competitiveness and productivity in these organizations. They are dependent on strong external positioning and control. In this type of culture, all the activities are based on profit and emphasis on rational action. It assumes that planning and goal setting results into productivity and efficiency [51].

In a market culture in an organization the main task of both an organization as a whole and each employee individually is the achievement of planned goals by a fixed time. And these goals, as well as the striving for their achievement, hold an organization together. As a rule, these goals are defined in quantitative economic terms. For example, to increase a profit by 15 percent by the end of the year, or to expand a market niche twice. In this culture, the organization emphasizes competition both outside and inside. Leaders are tough and demanding competitors. Success is defined in terms of market winning [52]. In addition, the market culture focuses on the transactions with the environment outside the organization instead of on the internal management, and the organizational goal is to earn profits through market competition [53].

The market culture is regarded as a results-oriented workplace with emphasis on winning, outpacing the competition, escalating share price, and market leadership [54]. The market culture tends to be results oriented, where members value competitiveness, thoroughness, perfectionism, assertiveness and personal initiative [55]. Clan culture is in competition with market culture, while adhocracy culture is in competition with hierarchy culture [56]. Furthermore, highly collective organizations emphasize group harmony, cooperation and reward for enhancing employee performance [57]. Research has shown that some organizations are effective if the organization leans towards clan culture while others are effective towards adhocracy culture or hierarchy culture or market culture [58]. Theoretical arguments support the idea that organizational culture is related to organizational performance and long term effectiveness [59]. For instance, organizational culture is one of the key organizational assets that have been studied extensively in their association with organizational effectiveness based on the resource based view [60]. Accordingly, organizational culture can enhance performance in a large scale if it can be understood that what sustains a culture as the culture of an organization allows the employees to be acquainted with both the firm's history as well as current methods of operation and this specific detection endows the employees with guidance about expected and acceptable future organizational behaviors and norms. Thus, creating and influencing an adaptive culture is one of a manager's most important jobs [61]. As such, understanding of the shared values, based on the competing values framework will enhance managerial decision making in relation to implementation of corporate strategies in Private universities. Therefore, this current study is based on organizational culture using the CVF with a focus on its effect in implementation of corporate strategy in Private chartered universities in Kenya.

Hierarchy culture is simply identified through the domination of rule, system and procedure; and it emphasizes an environment that is relatively stable, where tasks and functions can be integrated and coordinated, uniformity in products and services can be maintained, and workers and jobs are under control [61]. Any changes in organization are absolutely impossible without official changes of corresponding procedures, guidelines and instructions [62]. The dominant leadership style in hierarchy cultures is that of the coordinator or organizer, rules and policies are the primary bonding mechanisms, and the strategic emphasis is on permanence and stability [63]. Hierarchy is self-centered, autonomous culture and so outside-oriented, competitive and innovative goals are poorly understood by those organizations sharing this type of culture [63]. This type of culture is important in this study because the strategic emphasis is on permanence and stability, hence, strategy implementation.

The model of the hierarchy organizational culture refers to a strongly structured and formalized organization, with precise and reinforced procedures, rules, policies. The strategy meant to secure organization efficiency relies on maintaining the stability and smooth running. This culture can be simply identified through the domination of rule, system and procedure. Hierarchy type act as functionally best when the duty to be done is well perceived and when duration is not a vital element. The hierarchy culture in an organization is concentrated on internal problems, stability, predictability, controllability, and efficiency. All kinds of work are formalized and structured. Everything is governed by procedures, guidelines, instructions that are mainly in writing. Orderliness is especially encouraged and any changes in organization are absolutely impossible without official changes of corresponding procedures, guidelines and instructions [64]. On the other hand, this type of culture has a clear organizational structure, standardized rules and procedures, and strict control, as well as defined responsibilities [65].

The hierarchical culture is self-centered, autonomous culture and the outside-oriented, competitive and innovative goals are not well understood by the organizations sharing this type of culture [66]. Moreover, the hierarchical culture provides insufficient flexibility for university environment. A number of special programs, procedures, guidelines and instructions to lead the members of the organization need to be developed. Hierarchy culture organizations need a well-marked strong leadership. However, this kind of 
leadership causes to decrease the flexibility of an organization and makes it critically dependent on the personality of a leader.

The hierarchy culture is where an organization focuses on internal maintenance, strives for consistency and control through enforcement of strict rules [67]. The main characteristics of hierarchy culture are formalized and structured places along with procedures, well-defined processes and a smooth-running organization [68, 69, 70]. Therefore, the long-term concern of hierarchy culture is the stability, predictability, and efficiency [70]. Previous studies claim no relationship between organizational performance and bureaucratic cultures [71].

\section{Methodology}

In this research a positivist philosophy was used because the literature review has already been carried out to deduce the hypotheses from the existing literature.

The study used stratified random sampling which combines stratified sampling with random sampling [72]. Stratified random sampling was used in private chartered universities so as to have three strata. The strata were those under middle level management, academic staff, and students' leaders. Middle level management included the academic registrars, deans of schools, chairmen/heads of departments, and program directors. Academic staff included the professors, associate professors, senior lecturers, lecturers, and assistant lecturers, and students' leaders. Each of the three strata simple random sampling was done to identify individual participants who were issued with a questionnaire to respond to the research statements, and the interview.

The study used self-administered questionnaires to be able to obtain quantitative data for analysis to either refute or support the hypotheses. In development of the survey questionnaire, the variables for which information was collected was identified and followed by their operational definition. Self-introduction was the procedure for issuing the questionnaires to the participants. A researcher's letter of introduction accompanied the questionnaires and a data collection authority letter from the University. Primary data was collected through the administration of questionnaires to middle level management, academic staff, and students' leaders of Private chartered universities. Research assistants were trained and engaged to administer and follow up on the questionnaires. The specific objectives of the study were the key areas of investigation. Interviews were done to the Dean of Students, Finance Officers, Public Relations Officers, and Human Resource Managers.

Pilot testing is a small-scale trial of the proposed procedures, methods, materials, and it sometimes includes coding sheets and analytic choices. The importance of carrying out a pilot study is to test, revise, and then finalize the methods and the materials. Pilot testing is carried out to reveal any problems, and also to address these problems before the main study is carried out. A pilot study is an important means of assessing the usefulness and feasibility of the methods of data collection and making any necessary corrections before they are used with the research participants. Once the questionnaire is developed, a researcher should test it on small sample of participants to identify and eliminate potential problems. In order to test and refine the sampling methodology, the survey instrument and the procedures for data checking and analysis, a pilot survey was undertaken before concentrating on the major survey in the study areas [72]. pre-testing of questionnaire enhances clarity and it ensures the acceptance of the client of the survey, and one of the ways to do that is to use 3 to 6 experts - this does not apply, use another justification to read the survey and make some comments on it [73]. $10 \%$ of the participants were involved in the pilot test. The participants who took part in the pilot study were from one of the Private Chartered Universities that was not included in the collection process of the final data.

The researcher established the face validity by having experts or people who understand the study topic to read through the questionnaire. The experts evaluated whether the questions effectively capture the topic under investigation. The validity of the questionnaire was enhanced by doing a pilot test of a sample of $10 \%$ of the participants. The results generated from SPSS and their proposed changes were evaluated and considered for adjusting the questionnaire. Items from the questionnaire that did not reach the threshold were either be dropped or rewritten.

To avoid errors which might arise from ambiguity in giving instructions to the participants, research instruments need to be tested to ensure reliability. Three methods of ensuring reliability [74]. The methods are "test-retest reliability which refers to the consistency of an instrument when it is administered several times by the same person. This test was not applied in the study because of the challenge of availability of time to the researcher and completion of studies, and also the geographical spread of the participants. Inter-observer reliability refers to the consistency of an instrument when it is administered by different people. This test was applicable in this study. Internal consistency is when the instrument components are able to measure appropriately the same concept that is being studied. This test was carried out through pilot testing of the instruments using similar but different Private Chartered that are not religious-based. Findings were examined and weaknesses identified and addressed.

The reliability of the questionnaire was tested by the use of SPSS statistical software. To test reliability of the questionnaire, 24 questionnaires were piloted and the responses input into a statistical software and the results of the reliability test were produced. The researcher determined the Cronbach's alpha or reliability coefficient which estimated the internal consistency of data in measuring a given construct [75]. A Cronbach alpha reliability correlation coefficient should be around 0.70 . A coefficient of 0.80 or more implies that there is a high degree of reliability of the data [75].

Data processing and analysis is a process in which raw data is ordered and organized so that useful information can be extracted [76-78]. This process entails editing, coding, 
classification, tabulation and presentation of findings [79]. In this study, the collected data was first edited to eliminate ambiguity and obvious errors as well as enhance consistency and accuracy [79]. The data from questionnaires was organized, coded, analyzed and converted into quantitative summary reports for analyses using the statistical package for social sciences (SPSS) version 21 as the tool in order to describe the relationships between dependent and independent variables. This program was used to define the different quantitative variables under different categories. Data was then entered into the program under specific category from which analysis was run to obtain descriptive statistics, frequencies and percentages. Also qualitative data gathered through the interview guide was be condensed by editing, paraphrasing and summarizing in order to derive meaning from it.

The regression analysis yielded a coefficient of determination $\mathrm{R}_{2}$ or the amount of variation in efficient strategy corporate implementation in Private chartered universities [80]. A model element was deemed to have significant influence on the effect of organizational culture on implementation of corporate strategy, if the computed t-value of its regression coefficient will be greater than the critical t-value [81].

Qualitative data analysis generates a mass of words which are generated by interviews data and which need to be described and summarized. The researchers may be required to relate behavior or ideas to biographical characteristics of respondent such as age or gender, and they may also need to seek relationships between various themes that have been identified. Implications for policy or practice may be derived from the data, or interpretation sought of puzzling findings from previous studies [81]. In this kind of data, thematic areas shall be created and from these thematic areas, responses shall be classified and descriptive statistics generated. On the same, content analysis then done to enable derivation of conclusions.

Qualitative data provides for a description and interpretation of what things mean to people [82]. Qualitative data analysis seeks to make general statements on how categories or themes of data are related. In this research content analysis method will be used to analyze qualitative data. Content analysis describes the logical structure of expressions, categorizes phrases and ascertains associations, connotations, denotations; elocutionary forces and other interpretations [83]. This method was used because of its strength in compressing lengthy interviews and conversations. Using this method helps to make conclusions systematically and objectively because it identifies specified characteristics of information that is collected [84]. Qualitative data generated by interviews was analyzed by classifying responses from participants into main emerging themes, categorizing and coding the categories and assigning them numerical values. These values were processed by using SPSS to deduce descriptive statistics.

Factor analysis operates on the notion that observable and measurable variables could be reduced to fewer latent variables that share a common variance and are unobservable, which is known as reducing dimensionality [85]. These factors that are unobservable are essentially hypothetical constructs which are used to represent variables, but are not directly measured [86]. For someone to perform a factor analysis there has to be univariate and multivariate normality within the data [87]. It is also important that there is an absence of univariate and multivariate outliers [88]. On the other hand, a determining factor is based on the assumption that there is a linear relationship between the variables and factors when computing the correlations [89]. Depending on the design of the study, for something to be labeled as a factor it should have at least 3 variables [90]. Factor analysis was carried out on all items in each variable in order to reduce the measurable and observable variables to a few latent variables that share a common variance and are unobservable.

\section{Results and Discussions}

The researcher wanted to assess the effect of Market culture on implementation of corporate strategy in Private chartered universities in Kenya. The respondents were asked to state their level of agreement with the following items based on Market culture and how they are associated with implementation of corporate strategy in Private chartered universities in Kenya. The findings were as follows: On whether employees are achievement-oriented thus helping in strategy implementation, on scale of 1 to 5, an average score rate of 3.97 was recorded with standard deviation of 1.01 . Implying that majority of the respondents agreed that employees were achievement-oriented and this helps in strategy implementation in Private chartered universities in Kenya. The main task of a market-oriented culture is the achievement of planned goals by both an organization and each employee individually within a fixed time, and striving for the achievement of these goals hold an organization together [91]. A high level of marketing input into strategic management and promoted response to marketing intelligence as well as implementation of customer value enabling strategies describe a market-oriented culture. On the other hand, institutions that had Market-type cultures were most effective in the performance domains that are related to their ability to acquire the resources that were needed such as revenues, good faculty, and institutional visibility. All these attributes are consistent with a Market culture [92].

Based on whether the respondents were in agreement that their institutions emphasize competitive actions in the marketplace since score rate of 3.58 was registered with standard deviation of 1.03 . To know if productivity is emphasized within Private chartered universities, the result was clear since majority of the respondents strongly agreed with the statement, and this was supported with mean score of 4.61 and standard deviation of 0.98 . Similarly, to establish the extent to which the respondents were in agreement with whether the institutions are results-oriented thus enhancing successful strategy implementation, the result again confirmed that respondents were in agreement with the statement because an average scale of 3.85 and standard deviation of 


\subsection{0 was realized.}

To find out whether the respondents agreed that leadership in the institution demonstrates results-oriented focus, the outcome of the analysis a firm that leadership within private institutions demonstrates results-oriented focus because an average score of 3.85 and standard deviation of 1.03 was published. The finding also suggests that with good leadership which is focused within institution, then better returns will be realized. Studies show that leadership has a significant role play in the formation and carrying out of strategies [93]. The implication of this finding is that good leadership within institution causes great returns and that leadership has a significant role play in the formulation and implementation of strategies. To establish whether institution emphasizes on implementation of its objectives, again the findings were that majority of the respondents agreed that institutions emphasizes on implementation of its objectives and this was supported with an average score rate of 3.95 and standard deviation of 1.03 . To investigate if institution emphasizes on customer focus enable strategy implementation, the results showed that the respondents were in agreement that institution emphasizes on customer focus which enable strategy implementation. This was explained by the fact that a means score was 4.55 and standard deviation of 1.05. An organization that is customer focused is the one whose actions are consistent with a demonstrable customer relationship management strategy [94]. Instilling a strong market culture in an organization promotes competitive edge in market, promotes credibility and eases of purchase, customer loyalty and shared values. The summary of the findings are in table 1.

Table 1. Market culture Descriptive Analysis

\begin{tabular}{|c|c|c|c|c|c|c|c|}
\hline Statement & Strongly disagree & Disagree & Neutral & Agree & Strongly agree & Mean & Standard dev \\
\hline $\begin{array}{l}\text { Employees are achievement-oriented and this } \\
\text { helps strategy implementation. }\end{array}$ & $19(9.8)$ & $32(16.5)$ & $108(55.7)$ & $33(17)$ & $2(1)$ & 3.86 & .985 \\
\hline $\begin{array}{l}\text { Our institution emphasizes competitive actions } \\
\text { in the marketplace. }\end{array}$ & $2(1)$ & $24(12.4)$ & $41(21.1)$ & $84(43.3)$ & $43(22.1)$ & 3.77 & 1.106 \\
\hline Productivity is emphasized in our institution. & $2(1)$ & $14(7.2)$ & $12(6.2)$ & $105(54.1)$ & $61(31.4)$ & 4.26 & 1.346 \\
\hline $\begin{array}{l}\text { Our institution is results-oriented which } \\
\text { enhances successful strategy implementation. }\end{array}$ & $2(1)$ & $13(6.7)$ & $37(19.1)$ & $96(49.5)$ & $46(23.7)$ & 3.96 & 1.135 \\
\hline $\begin{array}{l}\text { Our institution emphasizes on implementation } \\
\text { of its objectives. }\end{array}$ & & $31(16)$ & $106(54.6)$ & $55(28.4)$ & $2(1)$ & 4.18 & .821 \\
\hline $\begin{array}{l}\text { To enable strategy implementation, our } \\
\text { institution emphasizes on customer focus. }\end{array}$ & & $11(5.7)$ & 27 (13.9) & $85(43.8)$ & $71(36.6)$ & 4.11 & .850 \\
\hline
\end{tabular}

\section{Qualitative Analysis for Market Culture}

The respondents were supposed to state the top three external environmental factors that hinder strategy implementation in their institutions. Economic factors had the majority of respondents $(28.5 \%)$ who indicated that this external environmental factor was hindering the implementation of strategies in their universities because fee is relatively higher than the competitors. The second highest response was $26.7 \%$ where the respondents indicated that competition is a hindrance to implementation of strategies. There is stiff competition from other universities especially the public universities. Social factors had $14.5 \%$ respondents who indicated that this was an external environmental factor, and close to this were the political factors where $12.7 \%$ respondents indicated that they affect the effective implementation of strategies. Technological factors and customers that were external environmental factors were indicated by $8.7 \%$ respondents. The implication of these findings show that there are several external environmental factors that hinder implementation of strategies, and these factors include economic, competition, social, political, technological factors, and customers. Table 2 gives the summary of the external environmental factors.

Table 2. External Environmental Factors

\begin{tabular}{lll}
\hline Main Factors & Frequency & Percent \\
\hline Economic factors & 49 & 28.49 \\
Competition & 46 & 26.74 \\
Social factors & 25 & 14.54 \\
Political factors & 22 & 12.79 \\
Technological factors & 15 & 8.72 \\
Customers & 15 & 8.72 \\
Total & 172 & 100 \\
\hline
\end{tabular}

The respondents were also supposed to indicate other external environmental factors that hinder strategy implementation in their institutions. Majority (17.9\%) respondents indicated government regulatory policies on education as an external environmental factor that affected implementation of strategies in their institutions. Successful implementation of strategies depends on having adequate information on changing technology in one's industry and 
government regulations and on knowing what the competitors are up to and what is generally happening both locally and global [94]. Further study found that frequent changes in government policies and regulations will negatively influence strategic planning and this becomes a hindrance to successful strategy implementation in institutions of higher learning in Kenya [95].

Large portion $(9.5 \%)$ of respondents indicated that a financial constraint was a great factor that hindered strategy implementation. About $8.3 \%$ respondents felt that movement of teaching staff, low staff morale caused by fear of retrenchment, and lack of incentives to staff and motivation. Still other respondents $(7.1 \%)$ stated that rigidity of adoption of new strategies and inability to embrace change (culture change) was another external factor that hindered implementation of strategies in Private universities. Lack of sufficient resources (land) for expansion/accommodation facilities and staff housing was indicated by $6 \%$ respondents as factors that hindered implementation of strategies. Few respondents $(3.6 \%)$ indicated that poor perception about private universities that did not sometimes get enough students to meet the quorum; tribalism, nepotism and corruption were a challenge in implementation of strategies in these universities. These findings imply that there are other environmental factors that hinder implementation of strategies and the Private chartered universities need to be aware of these factors and seek ways on how to eliminate them. Studies confirm that there are disputes between the management and lack of support from top level management in the organizations is an impediment to the implementation of corporate strategy because instead of management concentrating on how to implement strategies, they are caught up in squabbles, and hence becoming difficult to implement strategies though they are well formulated [96].

On the other hand, $2.4 \%$ respondents indicated that learning material and equipment expenses; limited human resource and mistrust; unnecessary religious influence; and lack of adaptability and quality are external factors that hinder effective implementation of strategies. But the least respondents, $1.2 \%$ stated that change in market environment, global benchmarks, lack of good will, insecurity, dynamics of learning environment, and market fluctuations are other factors that hinder strategy implementation. The findings imply that there are other external environmental factors that hinder implementation of strategies and these include government regulatory policies on education, financial constraint, movement of teaching staff, low staff morale caused by fear of retrenchment, and lack of incentives to staff and motivation, and rigidity of adoption of new strategies and inability to embrace change (culture change). The Private chartered universities need to be aware of these mentioned factors so that they could improve in their implementation of corporate strategies. However, 3.6\% respondents indicated internal environmental factors as poor communication, and $2.4 \%$ indicated that stakeholders' commitment is minimal. Further studies confirm this finding by pointing out that there is lack of communication between the formulators of strategies and the employees, and employees are not well informed about the strategies and the various tasks they are supposed to perform [97]. The findings imply that these internal environmental factors, that is, poor communication, and minimal of stakeholders' commitment make it hard to implement strategies in Private chartered universities in Kenya. Table 3 gives the summary other environmental factors, and also some few internal environmental factors.

Table 3. Other external environmental factors

\begin{tabular}{lll}
\hline Main Factors & Frequency & Percent \\
\hline Government regulatory policies on education & 15 & 17.86 \\
Financial constraint & 8 & 9.52 \\
Movement of teaching staff, low staff morale caused by fear of retrenchment, and lack of incentives to staff and motivation & 7 & 8.33 \\
Rigidity of adoption of new strategies and inability to embrace change (culture change) & 6 & 7.14 \\
Lack of sufficient resources (land) for expansion/accommodation facilities and staff housing & 5 & 5.95 \\
Poor perception about private universities/not getting enough students to meet the quorum & 3 & 3.58 \\
Tribalism, Nepotism and corruption & 3 & 3.58 \\
Learning material and equipment expenses & 2 & 2.38 \\
Limited human resource and mistrust & 2 & 2.38 \\
Unnecessary religious influence & 2.38 \\
Lack of adaptability and quality & 2.38 \\
Change in market environment and global benchmarks & 2 & 2.38 \\
Lack of good will and insecurity & 2.38 \\
Dynamics of the learning environment and market fluctuations & 2.38 \\
Internal environmental factors: & 2.38 \\
Poor communication & & 2 \\
Stakeholders commitment is minimal & 3 & 3.57 \\
Total & 2.38 \\
\hline
\end{tabular}

In order to determine the effect of market culture on the implementation of corporate strategy in Private chartered universities in Kenya, the following objective research hypothesis was developed.
$\mathrm{H}_{\mathrm{A}}$ : Market culture has positive significant effect on the implementation of corporate strategy in Private chartered universities in Kenya.

The results are presented in Table 4. 
Table 4. Inferential analysis of market culture.

\begin{tabular}{|c|c|c|c|c|c|c|c|}
\hline \multicolumn{8}{|c|}{ Model Summary } \\
\hline Model & & $\mathbf{R}$ & \multicolumn{2}{|c|}{ R Square } & Adjusted R Square & \multicolumn{2}{|c|}{ Std. Error of the Estimate } \\
\hline 1 & & $.474^{\mathrm{a}}$ & \multicolumn{2}{|c|}{.224} & .220 & \multicolumn{2}{|c|}{.40952} \\
\hline \multicolumn{8}{|c|}{ ANOVA $^{a}$} \\
\hline \multicolumn{3}{|c|}{ Model } & Sum of Squares & df & Mean Square & $\mathbf{F}$ & Sig. \\
\hline \multirow{3}{*}{1} & Regression & & 9.272 & 1 & 9.272 & 55.288 & $.000^{\mathrm{b}}$ \\
\hline & Residual & & 32.031 & 191 & .168 & & \\
\hline & Total & & 41.303 & 192 & & & \\
\hline
\end{tabular}

\begin{tabular}{|c|c|c|c|c|c|c|}
\hline \multicolumn{7}{|c|}{ Coefficients $^{\mathrm{a}}$} \\
\hline \multirow{2}{*}{ Model } & & \multicolumn{2}{|c|}{ Unstandardized Coefficients } & \multirow{2}{*}{$\begin{array}{l}\text { Standardized Coefficients } \\
\text { Beta }\end{array}$} & \multirow{2}{*}{$\mathbf{t}$} & \multirow{2}{*}{ Sig. } \\
\hline & & B & Std. Error & & & \\
\hline \multirow{2}{*}{1} & (Constant) & .568 & .348 & & 1.631 & .005 \\
\hline & market culture & .719 & .097 & .474 & 7.436 & .000 \\
\hline
\end{tabular}

The regression results in the table show that the effect of market culture on implementation of corporate strategy was significant $(\mathrm{F}(1,191)=55.288, \mathrm{p}=0.000<0.05)$. With $\mathrm{R}$ $=0.474$ and $\mathrm{R}^{2}=0.224$, the model implies that about $47.4 \%$ of implementation of corporate strategy was contributed by market culture a variation of $22.4 \%$ in implementation of corporate strategy were brought about by market culture.

The F test was significant with a $p$ value $=0.000$ which was less than the standard $\mathrm{p}$ value of 0.05 and this meant that the model was significant. From ANOVA, since $p$ value $p=0.000$ and was lower than $p=0.05$ ( $p$ value $0.00<0.05$ ). Therefore the hypothesis thatmarket culture has positive significant effect on the implementation of corporate strategy in Private chartered universities in Kenya was accepted. Therefore the contribution of market culture was significant. The equation that was fitted for the model was

$$
\text { implementation of corporate strategy }=0.568+0.719 \text { market culture }
$$

To ascertain the effect of hierarchy culture on the implementation of corporate strategy in Private chartered universities in Kenya, the following hypothesis was developed:
$\mathrm{H}_{\mathrm{A}}$ : Hierarchy culture has positive significant effect on the implementation of corporate strategy in Private chartered universities in Kenya. The results were presented in Table 5:

Table 5. Inferential analysis of hierarchy culture.

\begin{tabular}{|c|c|c|c|c|c|c|}
\hline \multicolumn{7}{|c|}{ Model Summary } \\
\hline Model & $\mathbf{R}$ & \multicolumn{2}{|c|}{ R Square } & Adjusted R Square & \multicolumn{2}{|c|}{ Std. Error of the Estimate } \\
\hline 1 & $.809^{\mathrm{a}}$ & \multicolumn{2}{|c|}{.654} & .652 & \multicolumn{2}{|l|}{.27422} \\
\hline \multicolumn{7}{|c|}{ ANOVA $^{\mathrm{a}}$} \\
\hline \multicolumn{2}{|c|}{ Model } & Sum of Squares & Df & Mean Square & $\mathbf{F}$ & Sig. \\
\hline \multirow{3}{*}{1} & Regression & 27.010 & 1 & 27.010 & \multirow[t]{3}{*}{359.184} & \multirow[t]{3}{*}{$.000^{\mathrm{b}}$} \\
\hline & Residual & 14.287 & 190 & .075 & & \\
\hline & Total & 41.297 & 191 & & & \\
\hline \multicolumn{7}{|c|}{ Coefficients $^{\mathrm{a}}$} \\
\hline \multirow{2}{*}{ Model } & & \multicolumn{2}{|c|}{ Unstandardized Coefficients } & Standardized Coefficients & \multirow{2}{*}{$\mathbf{t}$} & \multirow{2}{*}{ Sig. } \\
\hline & & B & Std. Error & Beta & & \\
\hline \multirow{2}{*}{1} & (Constant) & .462 & .143 & & 3.227 & .001 \\
\hline & hierarchy culture & .842 & .044 & .809 & 18.952 & .000 \\
\hline
\end{tabular}

The regression results in the table show that the effect of hierarchy culture on implementation of corporate strategy was significant $(\mathrm{F}(1,190)=359.184, \mathrm{p}=0.000<0.05)$. With $\mathrm{R}$ $=0.809$ and $\mathrm{R}^{2}=0.654$, the model implies that about $80.9 \%$ of implementation of corporate strategy was contributed by hierarchy culture a variation of $65.4 \%$ in implementation of corporate strategy were brought about by hierarchy culture.

The $\mathrm{F}$ test was significant with a $\mathrm{p}$ value $=0.000$ which was less than the standard $\mathrm{p}$ value of 0.05 and this meant that the model was significant. From ANOVA, since $p$ value $p=0.000$ and was lower than $\mathrm{p}=0.05$ ( $\mathrm{p}$ value $0.00<0.05$ ) therefore the hypothesis that hierarchy culture has positive significant effect on the implementation of corporate strategy in Private chartered universities in Kenya was accepted. It implies that the contribution of hierarchy culture was significant. The equation that was fitted for the model was 


\section{Conclusions}

The results established that there was positive effect of Market culture on implementation of corporate strategy in Private chartered universities in Kenya. For the null hypothesis tested, there was no effect of Market culture and implementation of corporate strategy in Private chartered universities in Kenya against the alternative that there was significant effect of Market culture and implementation of corporate strategy in Private chartered universities in Kenya.

Regression analysis established that there was effect of Market culture on the Implementation of corporate strategy in Private chartered universities in Kenya. Besides that, the coefficient of regression between Market culture and implementation of corporate strategy in Private chartered universities in Kenya. The results implied that there was a positive significant effect of Market culture on implementation of corporate strategy in Private chartered universities in Kenya. From the analysis the null hypotheses were rejected and the alternative hypothesis accepted for the two models, that is, when the moderator is not available and when the moderator is available.

The linearity test was done and the analysis indicated that using correlation coefficients and the results established that there was linear relationship between independent variable (Market culture) and Strategy implementation, and it was clear that there was positive relationship between Strategy implementation and Market culture.

Based on the results, it was established that the institutional policies generally governed what people did in implementing strategies. The respondents were in agreement that leadership in the institution demonstrated efficient coordination of strategy implementation, and that their institutions' efficiency relied on maintaining steady operations in strategy implementation. Their institutions defined success on the basis of smooth performance towards strategy implementation and that management style in the institution was characterized by efficiency which helps in strategy implementation.

Regression analysis established that model two was much better than model one. Further analysis suggested that the overall model was significant for two models, that is, the independent variable hierarchy culture was a good explanatory variable for strategy implementation when moderator is available showing that the two model were fit. The p-value published showed that there was a positive effect of hierarchy culture on implementation of corporate strategy in Private chartered universities in Kenya.

The linearity test was done and the study adopted the Pearson moment's correlation coefficients where the results indicated that the variables had a strong positive relationship. This implied that an increase in Hierarchy culture would result in a linear increase in Strategy implementation.

The findings of this study brought about several recommendations that would benefit both Public and Private University management, government of Kenya, Corporations and other education stakeholders. The study recommends that university leadership and other stakeholders should communicate effectively the formulated strategies to enable their staff to implement these strategies.

The study would assist the Management to have reward systems where employees are rewarded for their achievement or hard work because in some Private chartered universities there is lack of proper structures of promotion and remuneration, but tribalism and skewed promotions. Managers need to consider having an open door policy where students as stakeholders are not allowed to have some powers to manipulate university processes or where the management becomes too lenient to the students; and at times the students not heard at all.

This study has revealed findings that bring on board policy implications. Private chartered universities in Kenya play a very significant role through teaching, training and research which help the development of the country. They are influential in transmitting knowledge and in giving solutions to the problems facing the Kenyan universities through the awareness of the right kind of organizational that enable implementation of strategies. Therefore, organizational culture and implementation of strategies in Private chartered universities is important. The results of this study have come up with some important highlights that need to be given attention.

The findings of the study added knowledge by giving rise to insights that were valuable for academic and university leadership measures. Therefore the results of this study were of absorption to leadership of Private chartered universities that implemented strategies and management practices. The first implication of the study was that university leaders need to have proper, consistent and effective communication especially with regard to new policies and changes or the culture of communication and work ethic of the leadership. The study showed that poor communication with key stakeholders means that some are always lagging behind generating unnecessary conflicts and disagreements. This study established that university leadership, employee participation, and strategy communication were the main factors with practical implications for Private chartered universities in Kenya. The study also revealed that Private chartered universities had failed to communicate their formulated strategies to the staff to be able to implement them.

This study established that university leadership, employee participation, and strategy communication were the main factors with practical implications for Private chartered universities in Kenya. The study also revealed that Private chartered universities had failed to communicate their formulated strategies to the staff to be able to implement them. The Management needs to be efficient and student centric, and to use effective disciplinary rules to govern up the students. The study showed that Strategic planning needed to be done with the available resources.

The Management needs to make sure that there is level of commitment of university staff to organizational values. There should be involvement or participation and consultation of different stakeholders as directed by the Management. The 
Management to check the over-reliance on adjunct faculty amidst very low remuneration scales that does not match competition. The Management needs to cover the gap that is there between the management board and employees which results to workers not being appreciated.

The Management needs to check unnecessary retrenchment and firing of staff and job insecurity. Quality management meetings are important, but the Management should avoid having too many meetings to react to situations. The management also needs to adopt current technology and innovation, and continual upgrading of ICT facilities.

This study was mainly anchored on the contingency theory, the open systems theory, human resource development theory, McKinsey 7-S theory, and Noble's strategy implementation framework. The findings of this study contributed to the much needed empirical abundance to these theories, and especially competing values framework and the MacKinsey 7-S theory. The competing values framework is one of the models that have been applied to measure a typology of organizational culture and it uses two dimensions to group culture into four types. The quadrants of the CVF refer to hierarchy, market, clan, and adhocracy cultures, respectively. This study has confirmed and given summary of the framework's beliefs by plainly indicating the variable indicators that explain the variables which include clan culture, adhocracy culture, market culture, hierarchy culture, quality assurance, and corporate strategy implementation. The 7-S framework emphasizes fit between all the seven elements, that is, structure, strategy, systems, skills, style, staff, and shared values. The study also further magnified the MacKinsey 7-S theory's beliefs by establishing the involvement of each independent variable to moderating variable (quality assurance) and dependent variable (corporate strategy implementation). Further, the working and appropriateness of this theory has been scrutinized in Private chartered universities in Kenya which shows this theory has wide scope.

\section{References}

[1] Baek-Kyoo, Aaltonen, P. \& Ikavalko, H. (2002). Implementing strategies successfully. Integrated Manufacturing Systems, 13 (6): 415-418.

[2] Abagi, O. (2006). Private Higher Education in Kenya. In UNESCO's Growth and expansion of private higher education in Africa, 75-94. Retrieved from http://www.unesco.org/iiep

[3] Aboajela, S. M. (2015). The influence of organizational culture on performance measurement systems in Libyan Higher Education (Doctoral thesis). University of Huddersfield, Libya.

[4] Abok, A. M. (2010). Factors affecting implementation of strategic plans in Non-governmental organizations in Kenya ( $\mathrm{PhD}$ Thesis). Jomo Kenyatta University of Agriculture and Technology, Juja, Kenya.

[5] Abu-Jarad, I. Y., Yusof, N. A. \& Nikbin, D. (2010). A review paper on organizational culture and organizational performance. International Journal of Business and Social Science, Vol. 1 No. 3: December 2010
[6] Academy Administrative Practice (2015). Best practices in improving reputation and brand recognition in higher education. Arlington, VA: Hanover Research.

[7] Ahmadi, S. A. A., Salamzadeh, Y., Daraei, M. \& Akbari, J. (2012). Relationship between organizational culture and strategy implementation: Typologies and dimensions. Global Business and Management Research: An International Journal, Vol. 4, No. 3 \& 4, pp. 286-299.

[8] Akio, T. (2005). The critical assessment of the resource-based view of strategic management: The source of heterogeneity of the firm. Ritsumeikan International Affairs, Vol. 3, pp. 125-150. Retrieved from

http://www.ritsumei.ac.jp/acd/re/k-rsc/ras/english/publications /ria_en/03_8.pdf

[9] Allen, M. R., Ericksen, J. \& Collins, C. J. (2013). Human resource management, employee exchange relationships, and performance in small businesses. Human Resource Management, 52, 153-173. doi: 10.1002/hrm.21523.

[10] Allwood, C. (2012). The distinction between qualitative and quantitative research methods is problematic. Quality \& Quantity, 46, 1417-1429. Doi: 10.1007/s11135 011-9455-8.

[11] Ambani, N. J. \& Wanyoike, D. (2014). Effects of Communication on the Success of Strategy Implementation Process among Commercial Banks in Nakuru County Kenya. International Journal of Science and Research, Volume 3, Issue 10, October 2014.

[12] Analoui, F. \& Karami, A. (2003). Strategic management in small and medium enterprises. Great Britain: Thomson Learning.

[13] Anderson, D. R., Sweeney, D. J. \& Williams, T. A. (2003). Modern Business Statistics (5th ed.). Ohio: Southern-Western (Thompson learning).

[14] Antic, M.\& Ceric, A. (2008). Organizational culture of faculty of civil engineering, University of Zagreb, 8th International Conference, Organization, Technology, Management in Construction, Zagreb. Retrieved from http://crosbi.znanstvenici.hr/datoteka/396954.Antic20Ceric.pdf

[15] Ashmos, D. P., Duchon, D., McDaniel, R. R. Jr.\& Huonker, J. W. (2002). What a mess! Participation as a simple managerial rule to "complexity" organizations. Journal of Management Studies, 39 (2), 189-206.

[16] Athanasiou, T., Debas, H. \& Darzi, A. (2010). Key topics in surgical research and methodology. Berlin, Heidelberg: Springer-Verlag.

[17] Atwebembeire, J., Musaazi, J. C. S., Sentamu, P. N. \& Malunda, P. N. (2018). Performance Monitoring and Quality Teaching and Research in Private Universities in Uganda. International Journal of Learning, Teaching and Educational Research, Vol. 17, No. 10, pp. 70-85, October 2018. https://doi.org/10.26803/ijlter.17.10.5

[18] Balthazard, P. A., Cooke, R. A. \&Potter, R. E. (2006). Dysfunctional Culture, Dysfunctional Organization: Capturing the Behavioral Norms that Form Organizational Culture and Drive performance. Journal of Managerial Psychology, 21 (8), pp. 709-732.

[19] Bartholomew, D., Knotts, M. \& Moustaki, I. (2011). Latent variable models and factor analysis: A unified approach (3rd ed.). West Sussex, UK: John Wiley \& Sons. 
[20] Becker, C. \& Palmer, S. (2009). Branding in universities: Identity versus image - a case study of a Swedish University. Masters' Thesis, Lulea University of Technology, Sweden, June 2009.

[21] Beer, M. \& Eisenstat, R. A. (2000). Implementing strategies successfully. Integrated Manufacturing Systems, 13 (6): 415-418.

[22] Berlings, D., Beerten, Z., Hulpiau, V. \& Verhesschen (2010). Quality culture in higher education: from theory to practice. European University Association, July 19, 2010.

[23] Beytekin, O. F., Yalçınkaya, M., Doğan, M. \& Karakoç, N. (2010). The organizational culture at the university. The International Journal of Educational Researchers, 2010, 2 (1): $1-13$.

[24] Birn, R. J. (2004). The international handbooks of market research techniques. London, United Kingdom: Kogan Page Limited.

[25] Blass, E. \& Hayward, P. (2014). Innovation in higher education; will there be a role for "the academe/university" in 2025? Eur J Futures Res (2014) 2: 41 DOI 10.1007/s40309-014-0041-x.

[26] Bodenmuller, H. F. (2014). Leadership as a framework for successful strategy implementation. Hamburg, Germany: Anchor Academic Publishing.

[27] Boezerooij, P. (2006). E-learning strategies of higher education institutions: An exploratory study into the influence of environmental contingencies on strategic choices of higher education delivery and support processes. Czech Republic: CHEPS/UT.

[28] Bolboli, S.\& Reiche, M. (2014). Culture-based design and implementation of business excellence. The TQM Journal, 26, 329-347. Doi: 10.1108/TQM-01-2014-0015.

[29] Bonnell, J. R. (2015). Changing landscapes in Kenyan Higher Education: An Analysis of the impact of shifting contexts upon Religious-oriented universities (PhD Dissertation). Michigan State University, USA.

[30] Brinkschröder, N. (2014). Strategy implementation: Key factors, challenges and solutions. University of Twente, Faculty of Management and Governance. The Netherlands.

[31] Brown, J. D. (2002). Statistics Corner: Questions and answers about language testing statistics: The Cronbach alpha reliability estimate. Shiken: JALT Testing and Evaluation SIG Newsletter, $6(1), 14-16$.

[32] Cahoy, E. (2016). Empirical research in education and the behavioral/social sciences. The Pennsylvania State University. $\mathrm{http}: / / g u i d e s . l i b r a r i e s . p s u . e d u e m p /$

[33] Cameron, K. S. \& Freeman, S. L. (1991). Cultural congruence, strength and type: Relationships to effectiveness. Research in Organizational Change and Development, 5, 23-58, 1991.

[34] Cameron, K. S. \& Quinn, R. E. (1999). Diagnosing and changing organizational culture based on the competing values framework. Cohen, New York: Addison-Wesley Publishing Company, Inc.

[35] Cameron, K. S. \& Quinn, R. E. (2000). Diagnosing and Changing Organizational Culture. Upper Saddle River, New Jersey: Pearson Education, Inc.

[36] Cameron, K. S., Quinn, R. E., Degraff, J. \& Thakor, A. V.
(2006). Competing values leadership: Creating value in organizations. London: Edward Elgar.

[37] Cameron, K. S., Quinn, R. E. (2011). Diagnosing and changing organizational culture: The competing values framework. Reading, MA: Addison-Wesley.

[38] Cameron, K. S., Quinn, R. E., Degraff, J. \& Thakor, A. V. (2014). Competing values leadership ( $2^{\text {nd }}$ ed. $)$. Cheltenham, UK: Edward Elgar Publishing Limited.

[39] Campbell, D., Edgar, D. \& Stonehouse, G. (2011). Business strategy: An introduction. New York, NY: Palgrave Macmillan.

[40] Cargan, L. (2007). Doing social research. Maryland: Rowman \& Littlefield Publishers, Inc.

[41] Carriger, M. S. (2000). Research Design. Retrieved from http://dogbert.mse.cs.cmu.edu/Mse2001/Studio/resdes.pdf

[42] Cattell, R. B. (1973). Factor analysis. Westport, CT: Greenwood Press.

[43] Cater, T.\& Pucko, D. (2010). Factors of effective strategy implementation: Empirical evidence from Slovenian business practice. Journal for East European Management Studies, 15 (3), 207-236.

[44] Chemwei, B., Leboo, C. \&Koech, S. J. (2014). Factors that impede the implementation of strategic plans in secondary schools in Baringo District, Kenya. International Journal of Humanities and Social Science. Vol. 4, No. 5 (1), March 14.

[45] Chepkoech, C. \& Waiganjo, E. W. (2015). Role of stakeholders in the implementation of strategic change in commercial banks in Kenya: A case study of National Bank of Kenya Limited. International Academic Journal of Human Resource and Business Administration, 1 (5), 55-82.

[46] Chidambaranathan, K. \& Sakthi, R. V. (2016). Diagnosing the organizational culture of Higher Education Libraries in the United Arab Emirates using the Competing Values Framework. Libres, volume 26, issue 2, pp. 99-112.

[47] Child, D. (2006). The essentials of factor analysis ( ${ }^{\text {rd }}$ ed.). New York, NY: Continuum International Publishing Group.

[48] Chiuri, B. W. (2015). Challenges of strategy implementation in higher education institutions in Kenya (PhD Thesis). Jomo Kenyatta University of Agriculture and Technology, Juja, Kenya.

[49] Cifuentes-Madrid, J. H., Couture, P. L. \& Llinas-Audet, X. (Eds.) (2015). Strategic management of Universities in the Ibero-American region: A comparative perspective. New York, NY: Springer Cham Heidelberg.

[50] Cohen, J, Cohen, P., West, S. G. \& Aiken, L. S. (2003). Applied multiple regression/correlation analysis for the behavioral sciences ( $3^{\text {rd }}$ edition). Mahwah, New Jersey: Lawrence Erlbaum Associates Publishers.

[51] Coldwell, D. \& Herbst, F. (2004). Business research. Cape Town, South Africa: Juta and Co. Ltd.

[52] Collis, J. \& Hussey, R. (2003). Business research: A practical guide to undergraduate and postgraduate students. Basingstoke: Palgrave Macmillan.

[53] Collett, P. L. (2008). Services cape and customer satisfaction: The role of strategy ( $\mathrm{PhD}$ Thesis). The University of Texas at Arlington. Ann Arbor, MI: Proquest LLC. 
[54] Commission for Higher Education (August 2008). Handbook on Processes for Quality Assurance in Higher Education in Kenya. Nairobi, Kenya.

[55] Commission for University Education (2012). Vision and mission. $\quad$ Retrieved on from http://www.cue.or.ke/index.php/about-us/vision-and-mission

[56] Commission for University Education (2014). Strategic Plan (2014-2018). Retrieved from http://www.cue.or.ke/index.php/about-us/strategic-plan

[57] Cooper, D. R. \& Schindler, P. S. (2006). Business research methods $\left(9^{\text {th }}\right.$ ed.). Boston, MA: McGraw-Hill Irwin.

[58] Cooper, D. R. \& Schindler, P. S. (2008). Business research methods. New York, NY: McGrawHill/Irwin.

[59] Cooper, D. R. \& Schindler, P. S. (2011). Business research methods $\left(12^{\text {th }}\right.$ ed.). New York, NY: McGraw-Hill Education.

[60] Cottrell, R. R. \& Mckenzie, J. F. (2005). Health promotion and education research methods: Using the five-chapter thesis/dissertation model. Sudbury, MA: Jones and Bartlett Publishers.

[61] Council (June 2008). Final draft consultative document: A strategy for excellence. The University of Botswana Strategic Plan to 2016 and beyond. University of Botswana, Botswana.

[62] Crittenden, V. L. \& Crittenden, W. F. (2008). Building a capable organization: The eightlevers of strategy implementation. Business Horizons, 2008, 51, 301-309.

[63] CUE News (September-December, 2016). A Commission for University Education Publication, Nairobi, Kenya.

[64] Cummings, T. G.\& Worley, C. G. (2005). Organization development and change. Mason, Ohio: South-Western Thomson.

[65] Cunningham, J. \& Harney, B. (2012). Strategy and strategists. Oxford, UK: Oxford University Press.

[66] Dadnino, G. B. (Ed.) (2012). Handbook of research on competitive strategy. Northampton, MA: Edward Elgar Publishing, Inc.

[67] Daft, R. L. (2011). The leadership experience (5th Edition). Mason, OH: South-Western Cengage Learning.

[68] Dauber, D., Fink, G. \&Yolles, M. (2012). SAGE Journals, March 22, 2012. Doi: 1177/2158244012441482.

[69] Deal T. \& Kennedy, A. (2011). Corporate cultures: The rites and rituals of corporate life. New York, NY: Perseus Books Publishing.

[70] Denison, D. R. \& Mishra, A. K. (1995). Toward a theory of organizational culture and effectiveness. Organization Science, 6 (2), pp. 204-223.

[71] Denison, D. R. (1990). Corporate culture and organizational effectiveness. New York, NY: John Wiley \& Sons.

[72] Desson, K. \& Clouthier, J. (2010). Organizational culture Why does it matter. Presented to the Symposium on International Safeguards. International Atomic Energy Agency. Vienna, Australia.

[73] Dixit, G. K. \& Nanda, T. (2011). Strategic alignment of organizational culture andclimate for stimulating innovation in SMEs. International Journal of Innovation, Management and Technology, Vol. 2, No. 1, February, 2011.
[74] Essentials of research design and methodology. Hoboken, NJ: John Wiley \& Sons, Inc.

[75] Maru, B. W. (2015). Application of The Mckinsey 7s Model in strategy implementation at the Kenya Revenue Authority (MBA Thesis). School of Business, University of Nairobi, Nairobi, Kenya.

[76] J., \& Ji Hyun, S. (2010). Psychological empowerment and organizational commitment: the moderating effect of organizational learning culture. Human Resource Development International, 13 (4): 425-441.

[77] Balakrishnan, C., \& Masthan, D. (2013). Impact of Internal Communication on Employee Engagement: A Study at Delhi International Airport. International Journal of Scientific and Research Publications, 3 (8), 1-13.

[78] Barney, J. (2001). Is the resource-based view a useful perspective for strategic management research? Yes. Academy of Management Executive, 26 (1), 41-56.

[79] Creswell, J. W. (2013). Research Design: Qualitative, Quantitative, and Mixed methods Luhanga, M. (2006). Strategic planning of higher education institutions in Africa: A case study of the University of Dar-es-Salaam. Selected Papers of Beijing Forum, 2006. Procedia, Social and Behavioral Sciences.

[80] Lund, D. B.(2003). Organizational culture and job satisfaction. Journal of Business \& Industrial Marketing, Vol. 18 Iss: 3, pp. 219-236.

[81] Lunenburg, F. C., \& Ornstein, A. C. (2008). Educational administration: Concepts and practices $\left(5^{\text {th }}\right.$ ed.). Belmont, CA: Thomson Higher Education.

[82] Mackay \& Gass, 2016). Second language research: Methodology and design ( $2^{\text {nd }}$ ed.). New York, NY: Routledge.

[83] Magutu, P. O., Mbeche, I. M., Nyamwange, S. O. \& Nyaoga, R. B. (2011). A Survey of Benchmarking Practices in Higher Education in Kenya: The case of public universities. IBIMA Business Review Vol. 2011 (2011), BIMA Publishing. Article ID 357694, 20 pages DOI: 10.5171/2011.357694.

[84] Manguru, R. W. (2011). Influence of strategic management Practices on performance of Naivas Limited. Unpublished MBA research project, Nairobi: University of Nairobi.

[85] Mango, D. R. (2014). Determinants of Successful Strategy Implementation: A Survey of Selected Public Schools in South Africa. International Journal of Business and Management Invention, 3 (1), 41-46.

[86] Manyasi, B. N. (2009). Crisis management: A Challenge in institutions of higher learning in Kenya. A conference paper presented at the 1st KIM Conference on Management. Journal of the KIM School of Management, 1, 280-285.

[87] Marczyk, G. R., DeMatteo, D. \& Festinger, D. (2010). Essentials of research design and methodology. Hoboken, NJ: John Wiley \& Sons, Inc.

[88] Teddlie, C. \& Tashakkori, A. (2009). Foundation of mixed methods research: Integrating quantitative and qualitative approaches in social and behavioral sciences. Thousand Oaks, CA: SAGE Publications, Inc.

[89] The Open University (2016). Engaging with educational research. Retrieved from http://www.open.edu/openlearn/education/educational-technol ogy-and-practice/educational-practice/engaging-educational-r esearch/content-section-3.1 
[90] Thomas, J. R., Nelson, J. K. \& Silverman, S. J. (2011). Research methods in physical activity ( ${ }^{\text {th }}$ edition $)$. Champaign, IL: Humanities Kinetics.

[91] Thompson, A. A., Strickland III, A. J. \& Gamble, J. E. (2009). Concepts and Techniques for Crafting and Executing Strategy: Tying Rewards and Incentives to Good Strategy Execution. Italy: The McGraw-Hill Companies.

[92] Thompson, S. K. (2012). Sampling ( $3^{\text {rd }}$ ed.). Hoboken, NJ: John Wiley \& Sons, Inc.
[93] Tierney, W. G. (2008). The impact of culture on organizational decision-making: Theory and practice in higher education. Sterling, VA: Sylus Publishing, LLC.

[94] Trompenaars, F. (1994). Riding the waves of culture: Understanding diversity in global business. Burr Ridge, ILL: Irwin. 